\title{
New sensitive real-time PCR targeting $p 28$ gene for detection of Ehrlichia canis in blood samples from dogs
}

\section{Patrícia Gonzaga Paulino $^{1^{*}}$ (iD) Tays Araujo Camilo ${ }^{1}$ (D) Miguel Angelo Leite Mota Junior ${ }^{1}$ Nathália Alves de Senne ${ }^{1}$ (D) Olga Lucia Herrán Ramirez ${ }^{1}$ (D) Renata Lins da Costa ${ }^{2}$ Carlos Luiz Massard ${ }^{2}$ (D) Huarrisson Azevedo Santos ${ }^{1}$ iD}

${ }^{1}$ Departamento de Epidemiologia e Saúde Pública (DESP), Instituto de Veterinária (IV), Universidade Federal Rural do Rio de Janeiro (UFRRJ), 23890-900, Seropédica, RJ, Brasil. E-mail: patgpaulino@gmail.com. "Corresponding author.

${ }^{2}$ Departamento de Parasitologia, Universidade Federal Rural do Rio de Janeiro (UFRRJ), Seropédica, RJ, Brasil.

ABSTRACT: This study aims to describe a new detection method of a quantitative real-time polymerase chain reaction ( $q$ PCR) targeting the $28 \mathrm{kDa}$ outer membrane protein gene (p28) as well as to compare this method with a conventional PCR (cPCR), which targets the same gene, in order to evaluate the performance of the technique designed in this study in detecting Ehrlichia canis (E. canis). Optimum oligonucleotides concentrations were reached, and the analytical sensitivity and specificity of the qPCR were performed. A total of 218 dogs' whole blood samples were conventionally collected for this study. The DNA was extracted from each sample. Subsequently, the samples were tested by an established CPCR and the new qPCR to compare each technique's performances. This new qPCR method for the molecular detection of $E$. canis presented a detection limit of ten copies of the fragment and was considered specific for E. canis according to analytical specificity analyses performed in vitro and in silico. The standard curve revealed $100 \%$ efficiency and a coefficient of determination $\left(R^{2}\right)$ equivalent to $99.8 \%$. Among the samples examined by qPCR, 24.31\% were considered positive, significantly greater than those detected by $c P C R$ (15.13\%). The qPCR technique reached a higher sensitivity than the $c P C R$ when targeting the p28 gene in detecting E. canis. The qPCR standardized in this study is an efficient method for confirming canine monocytic ehrlichiosis (CME) diagnosis and might provide the parasitemia monitoring during the disease treatment.

Key words: canine monocytic ehrlichiosis, molecular detection, diagnosis, hemoparasite.

Novo PCR em tempo real sensível que visa o gene p28 para a detecção de Ehrlichia canis em amostras de sangue de cães

RESUMO: Este estudo tem como objetivo descrever um novo método de detecção de uma reação em cadeia da polimerase quantitativa em tempo real ( $q P C R$ ) visando o gene da proteína da membrana externa de $28 \mathrm{kDa}(\mathrm{p} 28)$, bem como comparar este método com um PCR convencional (cPCR), que visa o mesmo gene, a fim de avaliar o desempenho da técnica desenhada neste estudo na deteç̧ão de Ehrlichia canis (E. canis). As concentrações ideais de oligonucleotideos foram alcançadas e a sensibilidade analitica e a especificidade do qPCR foram determinadas. Um total de 218 amostras de sangue total de cães foram coletadas convencionalmente para este estudo. $O$ DNA foi extraído de cada amostra. Posteriormente, as amostras foram testadas por um cPCR estabelecido e o novo qPCR para comparar os desempenhos entre cada técnica. A curva padrão revelou $100 \%$ de eficiencia e coeficiente de determinação ( $\left.R^{2}\right)$ equivalente a $99,8 \%$. Dentre as amostras examinadas por qPCR, 24,31\% foram consideradas positivas, percentual significativamente maior do que as detectadas por cPCR (15,13\%). A técnica qPCR atingiu uma sensibilidade maior do que a cPCR na deteç̧ão de E. canis. A qPCR padronizada neste estudo é um método eficiente para a confirmação do diagnóstico de erliquiose monocitica canina (EMC) e pode fornecer o monitoramento de níveis de parasitemia ao longo do tratamento da doença.

Palavras-chave: Ehrliquiose monocítica canina, detecção molecular, diagnóstico, hemoparasita.

\section{INTRODUCTION}

Ehrlichia canis is an obligatory intracellular hemoparasite that possesses major significance in veterinary medicine, namely in the tropical countries where this infection occurs with more frequency (AGUIAR et al., 2020). The vector Rhipicephalus sanguineus sensu lato (s.1.) must actively contribute toward raising the infection rates in tropical areas (VIEIRA et al., 2011). Moreover, this pathogen has zoonotic potential, representing a public health concern (NICHOLSON, 2010).

The disease produced by E. canis is called canine monocytic ehrlichiosis (CME). According to epidemiological and experimental studies, CME's clinical presentation results in acute, chronic, or 
subclinical phases (WANER et al., 1997; DE CASTRO et al., 2004; MYLONAKIS et al., 2004). However, these phase differences are not explicit in dogs with naturally occurring disease (HARRUS et al., 2012).

In the subclinical phase, dogs usually show mild to non-existent thrombocytopenia or do not show clinical signs (WANER et al., 1997). During this phase, E. canis presents low parasitemia, and it is not frequently present in the peripheral blood, which complicates pathogen detection. In addition to these factors, E. canis might be only found in determined organs. For these reasons, it is possible to obtain false-negative results in PCR on blood samples (RODRÍGUEZ-ALARCÓN et al. 2020). Despite this detection bias, many studies have shown that molecular techniques present fewer false-negative results for ehrlichiosis diagnosis than other methods (RAMOS et al., 2009; NAKAGHI et al., 2010).

Several PCR modalities were designed to improve the sensitivity of $E$. canis detection in laboratory methods (DOYLE et al., 2005; NAKAGHI et al., 2010). Nested PCR (nPCR) has been used routinely to detect $E$. canis to increase analytical sensitivity over cPCR (SALLES et al., 2015; VELOSO et al., 2018; AYAN et al., 2020). Notwithstanding, this method has a high contamination risk that may result in unexpected cross-amplifications (DOYLE et al., 2005). The quantitative real-time polymerase chain reaction (qPCR) has been widely used to confirm the CME diagnosis (BUNRODDITH et al., 2018). This method is used frequently due to the various advantages it provides, such as specificity, sensibility, reproducibility, low risk of contamination, elimination of the post-amplification process, a consequent reduction in the time required for the assay to obtain the result, and the possibility of estimating the absolute number of target copies in the sample (DOYLE et al., 2005; PAULINO et al., 2018).

Besides the diversity of PCR techniques, various molecular markers have been used to confirm CME diagnosis (QUROLLO et al., 2017). Sequences coding ribosomal DNA (rDNA) are highly conserved, and it is the most used molecular marker for $E$. canis detection. Nevertheless, discrimination between species should use moderately conserved genes rather than highly conserved, such as rDNA (LYMBERY \& THOMPSON, 2012).

DA COSTA et al. (2019) have reported that the $28 k D a$ surface-exposed antigen protein (p28) gene shows a significant degree of conservation among the Brazilian, American, and Asian samples $(99 \%)$, and also stated $79 \%$ homology with the closest organism, Ehrlichia chaffeensis. These results reveal that the p28 gene is moderately conserved among Ehrlichia species and highly conserved in the species E. canis, which are ideal characteristics for species discrimination using molecular methods. NAKAGHI et al. (2010) have already designed a conventional PCR highly specific targeting the $p 28$ gene. However, it presents low sensitivity due to the large size of the amplification product.

The present study aims to develop a sensitive qPCR method targeting the $p 28$ gene that may be used for specific detection of E. canis in clinical samples from naturally infected dogs as well as to compare this qPCR with a conventional PCR for targeting the $p 28$ gene of $E$. canis, as previously described by NAKAGHI et al. (2010).

\section{MATERIALS AND METHODS}

\section{Animal and sampling procedures}

A total of 218 whole blood samples were obtained by cephalic venipuncture in dogs from Small Animals Veterinarian Hospital at the Federal Rural University of Rio de Janeiro (HVPA-UFRRJ) from July 2017 to December 2017. These animals arrive at the hospital for various purposes. Some dogs were visiting to do check-ups or be vaccinated. Others presented non-specific clinical signs, for instance, lethargy, fever, pale mucous membranes, epistaxis, and hematological and biochemical disturbances.

The collected blood (2-3 mL) was stored in sterile tubes containing an anticoagulant (ethylenediaminetetraacetic acid) in the ultrafreezer $\left(-800^{\circ} \mathrm{C}\right)$. The performing and interpreting of the molecular assays and statistical analyses were conducted using the double-blinded method. These samples were used first to evaluate qPCR's diagnostic yield and compare the results with the cPCR, which targeted the $p 28$ gene.

\section{DNA extraction}

Deoxyribonucleic acid (DNA) extraction was performed using DNeasy Blood \& Tissue Kit (Qiagen, Valencia, CA, USA) and following the manufacturer's instructions. Subsequently, each DNA sample was quantified by the spectrophotometer Nanodrop ND-2000 ${ }^{\circledR}$ (Thermo Scientific, Wilmington, DE, USA); the concentration was standardized between samples at $50 \mathrm{ng} / \mu \mathrm{L}$.

\section{Reference DNA controls}

The DNA sample used as a standard positive control was collected from a sick dog presenting unspecific clinical manifestations. The cytological 
exam of the patient's blood was performed, and it presented a suggestive Ehrlichia-positive result due to intracellular basophilic inclusions in monocytic cells observed by microscopy. The confirmation of the CME diagnosis was concluded following the determination of the positive results by a cPCR that targeted the glycoprotein $19 \mathrm{kDa}$ (gp19) gene (HSIEH et al., 2010). The obtained amplicons were purified using a Clean Sweep kit (Applied Biosystems ${ }^{\circledR}$ ) and were sequenced using the Sanger method to confirm the result. The sequence showed $100 \%$ similarity with E. canis sequences from GenBank and was deposited with the number of accessions 'MG584542'.

The negative standard DNA control was extracted from a naïve dog raised in experimental conditions with an ectoparasites-free environment. Subsequently, the sample was tested by two different molecular methods to increase the confidence margin. The applied cPCR used the gp19 gene (HSIEH et al., 2010) and the $d s b$ gene as the target (DOYLE et al., 2005). The molecular reactions provided negative results. Nuclease-free water $\left(\right.$ Ambion $^{\circledR}$ ) was used as a negative amplification control.

\section{Optimization of $q P C R$}

Primers and probes were designed using Primer Express ${ }^{\circledR} 3.0$ (Thermo Fisher Scientific Inc., Waltham, MA, USA). The oligonucleotides were tested using available software (Oligo Explorer 1.2, Hawthorne, NY, USA) for annealing temperature, self-annealing, and dimerizing, among additional specific functions.

$\begin{array}{cr}\text { The primers } & \text { p28F } \\ \text { (5'-GGGTGGCCCAAGAATAGA-3') } & \text { and }\end{array}$
p28R (5'-GTTACTTGCGGAGGACATG-3') were designed to amplify a $143 \mathrm{bp}$ fragment of the E. canis-p28 gene. The hydrolysis probe chosen for use in this study was p28P (5'-VICTGCTTTATCTCATCATAGTTC-MGB-3'). A concentration primer test was performed to determine the required, ideal primer concentration to obtain the lowest cycle quantification $(\mathrm{Cq})$ with a maximum fluorescence signal according to the baseline $(\Delta R n)$ in the absence of non-specific points of dissociation temperature. For this purpose, according to the manufacturer's description, an experiment was conducted with three replicates of each of the sixteen conditions established for the concentration test (200 $\mathrm{nM}$ to $800 \mathrm{nM}$ ). Reactions were performed at the StepOnePlusTM Real-Time PCR System (Applied Biosystems, Foster City, CA, USA) in a total volume of $12 \mu \mathrm{L}$, comprising 1x SYBR ${ }^{\circledR}$ Green PCR Master Mix (Applied Biosystems, Foster City, CA, USA) and approximately 100 copies of E. canis-positive DNA as a template. The following thermocycling conditions were used: polymerase activation $95^{\circ} \mathrm{C}$ for 10 minutes, 40 cycles were run with 20 seconds denaturation at 95 ${ }^{\circ} \mathrm{C}, 30$ seconds annealing at $55^{\circ} \mathrm{C}$, and 30 seconds extension at $72{ }^{\circ} \mathrm{C}$. A dissociation curve was produced to confirm the specificity of the amplification.

After standardizing the primer concentrations, the optimum probe concentration was determined. Probe assays were run in three replicates for each concentration $(50 \mathrm{nM}, 100 \mathrm{nM}, 150 \mathrm{nM}$, $200 \mathrm{nM}$, and $250 \mathrm{nM}$ ) in a final volume of $12 \mu \mathrm{L}$, comprising 1x TaqMan ${ }^{\circledR}$ Universal PCR Master Mix (Applied Biosystems, Foster City, CA, USA), $200 \mathrm{nM}$ of each primer, approximately 100 copies of E. canispositive DNA as a template, and the respective probe concentration. During the qPCR assay analysis, it was possible to determine the ideal probe concentration based on the lowest $\mathrm{Cq}$ and the maximum $\Delta \mathrm{Rn}$.

\section{Reference $c P C R$ The}

$\begin{array}{llr}\text { described by NAKAGHI et al. } & \text { (2010) } \\ \text { using the } & \text { oligonucleotides } & \text { ECp28-F }\end{array}$
(5'-ATGAATTGCAAAAAAATTCTTATA-3') and ECp28-R (5'-TTAGAAGTTAAATCTTCCTCC-3') was chosen as the reference method for technique comparison considering both PCRs target the p28 gene. The reaction mix was set in a final volume of $25 \mu \mathrm{L}$ containing $1 \times$ PCR buffer $(100 \mathrm{mM}$ Tris- $\mathrm{HCl}$, $\mathrm{pH} 9.0,500 \mathrm{mM} \mathrm{KCl}), 0.2 \mathrm{mM}$ each dNTP, $2.5 \mathrm{mM}$ $\mathrm{MgCl} 2,500 \mathrm{nM}$ each primer, $1.25 \mathrm{U}$ of Taq DNA polymerase, and $150 \mathrm{ng}$ of sample DNA per reaction. The thermocycling conditions consisted of $95{ }^{\circ} \mathrm{C}$ for 5 minutes, 40 cycles at $95{ }^{\circ} \mathrm{C}$ for 30 seconds, the annealing temperature of $52{ }^{\circ} \mathrm{C}$ for one minute and $72{ }^{\circ} \mathrm{C}$ for two minutes, followed by a final extension at $72{ }^{\circ} \mathrm{C}$ for 5 minutes. The analytical sensitivity was evaluated based on the detection limit obtained through a tenfold dilution of the amplicon. The PCR products were submitted to electrophoresis and were run in a $2 \%$ agarose gel. The electrophoresis run was performed at $5 \mathrm{~V} / \mathrm{cm}$, and the gel staining was executed with ethidium bromide $(0.4 \mathrm{mg} / \mathrm{mL})$. The fragments were observed under ultraviolet light using the E-Gel Imager system (Invitrogen, Thermo Fisher Scientific Inc., Waltham, MA, USA). Samples were determined positives by the presence of a single band at the $823 \mathrm{bp}$ fragment height.

\section{Analytical sensitivity}

Two standard curves were created using serial decimal dilutions of amplicons obtained in 
cPCR for targeting the E. canis p28 gene to provide the analytical sensitivity of qPCR. However, one of the curves was spiked, in each of the dilution points, with $20 \mathrm{ng}$ of naïve dog's DNA from the reference negative DNA control to verify alteration in the qPCR performance. All amplicons obtained by this cPCR were purified with the Wizard ${ }^{\circledR}$ Genomic DNA Purification kit (Promega ${ }^{\circledR}$, Madison, WI, USA) and quantified using Qubit ${ }^{\circledR}$ (Thermo Fisher Scientific, Wilmington, DE, USA). The purified cPCR product obtained a concentration of $50.5 \mathrm{ng} / \mu \mathrm{L}$ and this value was applied to calculate copy number using the following equation: copy number $=\left(6.02 \times 10^{23}\right.$ (copies per mole) x DNA concentration $(\mathrm{g})$ ) / (target size (base pairs) x $660(\mathrm{~g} / \mathrm{mol} / \mathrm{bp}))$. The number of copies of the $p 28$ gene ranged from 1 to $10^{6}$ per $\mu \mathrm{L}$, with seven separate dilutions performed in triplicate. The linear regression along with the coefficient of determination $\left(\mathrm{r}^{2}\right)$ for each point of the curve was used to evaluate the efficiency of qPCR reactions, which was determined by considering the slope of the standard curve using the following formula: [Efficiency $=10$ (-1 / slope) -1 ] (SVEC et al., 2015).

\section{Analytical specificity}

The analytical specificity was evaluated through in silico analysis and in vitro assay. The in-silico analysis was performed to investigate the oligonucleotides' conservancy between the E. canis sequences and variable regions between Ehrlichia species. Sequences of the $p 28$ gene and orthologs from Ehrlichia spp. deposited in GenBank were aligned using the algorithm ClustalW from the Molecular Evolutionary Genetics Analysis version 7.0 (MEGA7) for the bigger datasets (KUMAR et al., 2016). The oligonucleotides' specificity to the E. canis $p 28$ gene sequences was also confirmed through the primerBLAST Algorithm (NCBI, Bethesda, DM, USA).

The in vitro assay was performed using various DNA pathogens frequently found in dogs from Brazil, such as Anaplasma platys, Anaplasma phagocytophilum, Ehrlichia chaffeensis, Babesia vogeli, Hepatozoon canis, and Rangelia vitalii; the pathogens were obtained from blood samples of naturally infected dogs (DOYLE et al., 2005; OTRANTO et al., 2011; SANTOS et al., 2013; PAULINO et al., 2018; SOARES et al., 2011; SILVA et al., 2016). Additionally, the assay contained other pathogens' DNA, for example, Leishmania infantum from cellular cultures, Babesia caballi, Theileria equi, and Neorickettsia risticii from horses, indicating suggestive clinical signs (BHOORA et al.,
2010; KIM et al., 2008; PUSTERLA et al., 2009), and Babesia bovis and Anaplasma marginale from naturally infected cattle (DE ECHAIDE et al., 1998; LINHARES et al., 2002). These animals had high parasitemia (in the acute phase), and their infections were detected by microscopy and confirmed by a specific molecular assay.

\section{Analysis of the presence of inhibitors}

A CPCR previously described by BRINKHOF et al. (2006) that targets a highly conserved gene of dogs (the Beta-actin protein) was performed, and the quality of DNA extraction was assessed through the spectrophotometer Nanodrop ND-2000 ${ }^{\circledR}$ (Thermo Fisher Scientific, Wilmington, DE, USA). An inhibitory analysis was performed to verify if the negative samples were truly negative or if the amplification was undermined because of the inhibitors' presence. The test was executed, adding ten copies of the $p 28$ gene fragment from $E$. canis in all negative sample aliquots presented in this study.

\section{Statistical analysis}

In order to predict the number of copies from the $\mathrm{Cq}$ value, a simple linear regression analysis was performed for standard curves with and without the addition of dog DNA. The two standard curves were compared, applying Student's t-test to verify if there is a difference between the regression coefficients (slope value) and y-intercept between the linear regression analyzes performed for each curve.

The results of the real-time PCR and conventional PCR, targeting the $p 28$ gene of $E$. canis, were evaluated by the McNemar Test at a $5 \%$ significance level using BioEstat 5.0 software. This analysis aimed toward measuring the proportion of disagreement between qPCR and $\mathrm{cPCR}$ for $E$. canis detection in dog blood samples.

\section{RESULTS}

The qPCR designed in this study presented $24.31 \%(n=53 / 218)$ of positive samples. By contrast, the cPCR presented $15.13 \%(n=33 / 218)$. All the positive samples of $\mathrm{cPCR}$ were tested positively by qPCR.

The designed oligonucleotides targeting the $p 28$ gene of E. canis proved to be specific in the in vitro analysis when tested against pathogens commonly found in dogs in Brazil, including $E$. chaffeensis (the closest species).

The primers' optimal concentration was set at $200 \mathrm{nM}$ for both forward and reverse settings, 
which achieved a Cq value of 26.08 cycles, an $\Delta \mathrm{Rn}$ of 0.867 , and no sign of dimerization using a standard sample with 100 copies of the E. canis $p 28$ gene as a template. The optimal probe concentration was 250 $\mathrm{nM}$, reaching the minimum $\mathrm{Cq}$ value of 29.95 with the higher $\Delta \mathrm{Rn} 0.900$ as the positive control.

The optimized reaction conditions developed in this study was a final volume of $12 \mu \mathrm{L}$, comprising 1x TaqMan $^{\circledR}$ Universal PCR Master Mix (Applied Biosystems, Foster City, CA, USA), $200 \mathrm{nM}$ of each primer, $250 \mathrm{nM}$ of the probe, and $150 \mathrm{ng}$ of DNA sample.

The standard curve (without the dog's DNA) presents six dilution points with the number of copies in the log scale plotted against the quantification cycle values (Figure 1). The achieved determination coefficient $\left(\mathrm{R}^{2}\right)$ was $99.8 \%$, the mean $\mathrm{Cq}$ values and standard error were from $19.12 \pm$ 0.06 in the first dilution point $\left(10^{6}\right.$ copies per $\left.\mu \mathrm{L}\right)$, $22.28 \pm 0.09$ in the second point $\left(10^{5}\right.$ copies per $\mu \mathrm{L}), 25.70 \pm 0.04$ in the third point $\left(10^{4}\right.$ copies per $\mu \mathrm{L}), 29.32 \pm 0.04$ in the fourth point $\left(10^{3}\right.$ copies per $\mu \mathrm{L}), 32.89 \pm 0.09$ in the fifth point $\left(10^{2}\right.$ copies per $\mu \mathrm{L}$ ), to $35.73 \pm 0.35$ in the last dilution point (ten copies per $\mu \mathrm{L}$ ) (Figure 1). An efficiency of $100 \%$ was reached in the standard curve built without adding dog DNA (Figure 1).
The standard curve (with the dog's DNA) presents six dilution points with the number of copies in the log scale plotted against the quantification cycle values (Figure 2). The achieved determination coefficient $\left(\mathrm{R}^{2}\right)$ was $99 \%$. An efficiency of $98.84 \%$ was reached in the standard curve with the dog's DNA (Figure 2).

The Student's $t$-test resulted in no significant difference between the linear regression analyzes of standard curves with and without the addition of dog DNA.

The analytical sensitivity of qPCR showed a detection limit of ten copies of the $E$. canis $p 28$ gene per $\mu \mathrm{L}$ in both standard curves.

All these results demonstrate that the developed qPCR method was efficient, specific, and sensitive for detecting E. canis DNA in blood from naturally infected dogs. In contrast, the analytical sensitivity of cPCR presented a detection limit of 100 copies per $\mu \mathrm{L}$. The quantification range of the $E$. canis $p 28$ gene found in the studied samples was ten to 28.183 copies per $\mu \mathrm{L}$.

The comparison between techniques revealed that qPCR presented a significantly higher number of positive samples in contrast with $\mathrm{cPCR}$, the former showing $24.31 \%(\mathrm{n}=53 / 218)$ and the latter showing $15.13 \%(n=33 / 218)$. The discordant

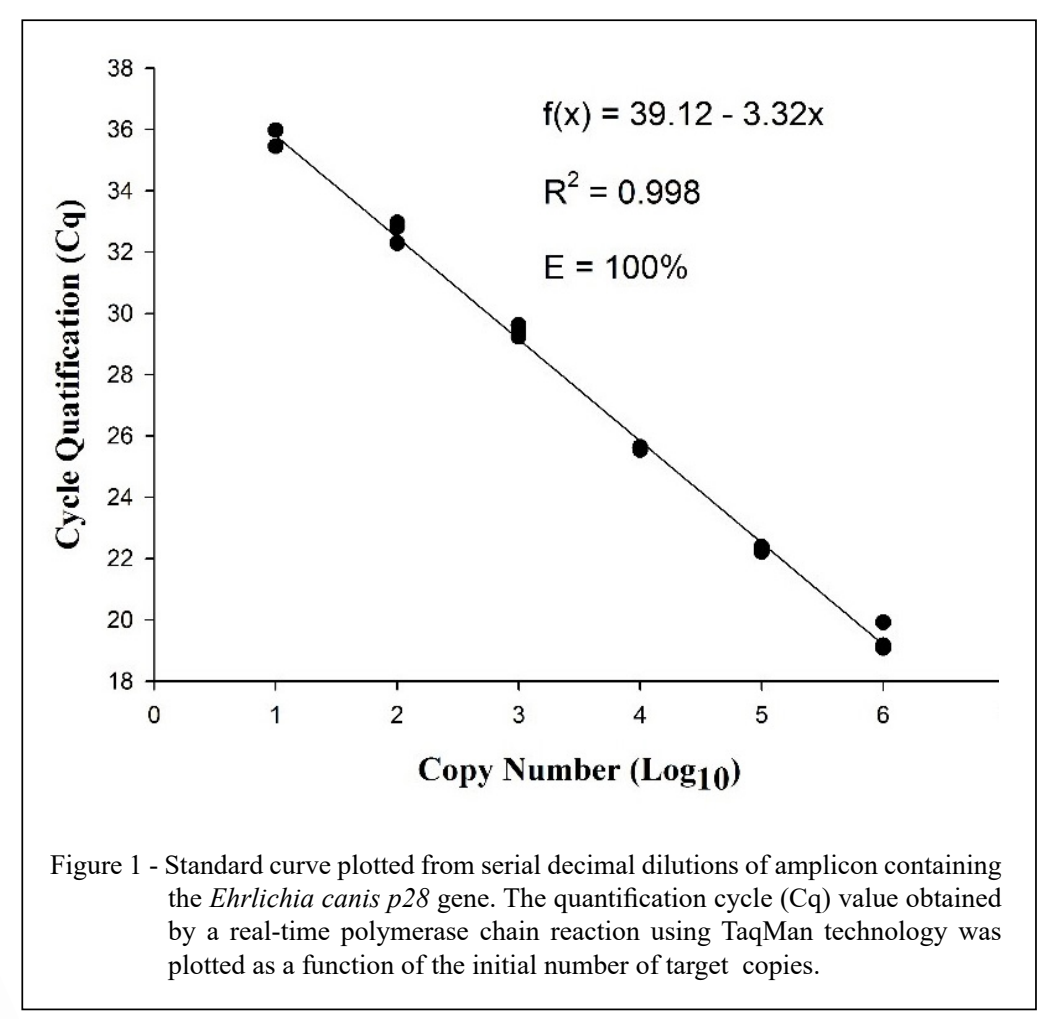

Ciência Rural, v.51, n.12, 2021. 


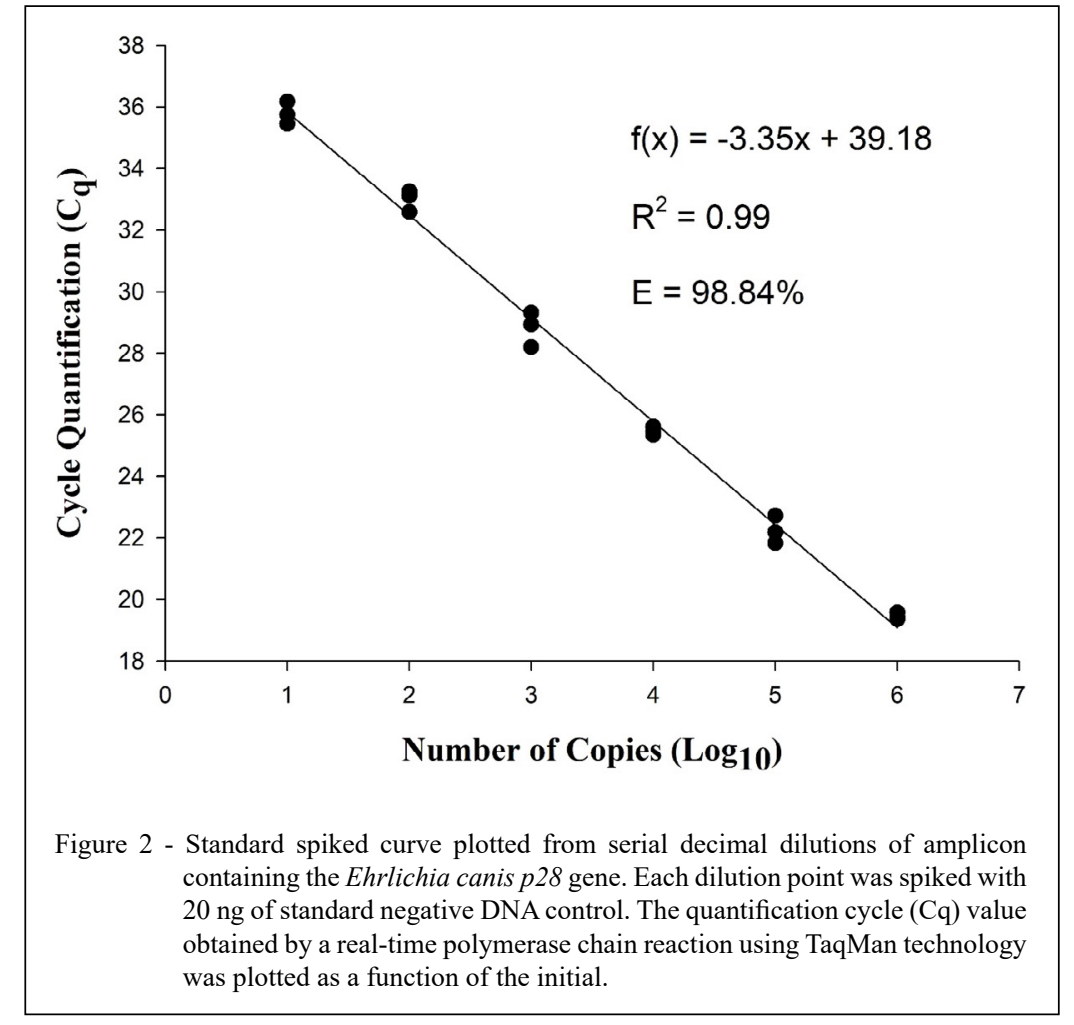

pairs (twenty samples) tested positively for qPCR and negatively for cPCR presented $\mathrm{Cq}$ values ranging from 37 to 39 cycles. The statistical analysis showed a significant difference $(\mathrm{p}<0.001)$ between the methods and favored the qPCR (Table 1).

\section{DISCUSSION}

Several real-time PCR protocols to confirm CME's diagnosis have been described during the last twenty years. DOYLE et al. (2005) described the multicolor qPCR as an assay capable of detecting and discriminating between $E$. chaffeensis, E. canis, and E. ewingii in a single reaction by amplifying a fragment of the $d s b$ gene as well as detecting co-infections within the same sample. Although this technique is frequently used, the reported analytical sensibility is 50 copies, which is higher than the present study's detection limit (ten copies). PELEG et al. (2010) design a probe-qPCR targeting the $16 \mathrm{~S}$ rDNA sequence. This qPCR assay exhibits the same detection limit found in the current study, albeit it does not present the same specificity level considering it reports primers with high conservancy between Ehrlichia species, E. canis.

QUROLLO et al. (2014) designed a qPCR assay displaying a detection limit of only five

Table 1 - Analysis of the disagreement between the real-time polymerase chain reaction (qPCR) and a conventional polymerase chain reaction (cPCR). A comparison of the results was obtained when samples were subjected to the detection of Ehrlichia canis.

\begin{tabular}{lccc}
\hline cPCR & & & \\
& Total & & \\
& Positive & Negative & $0^{*}$ \\
Positive & 33 & 165 & 33 \\
Negative & $20^{*}$ & 165 & 185 \\
Total & 53 & 218 \\
\hline
\end{tabular}

${ }^{*} P<0.001$ indicates significant disagreement between $p 28$-cPCR and $p 28-\mathrm{qPCR}$ by McNemar test.

Ciência Rural, v.51, n.12, 2021. 
copies. Meanwhile, it also displays a cross-reaction with $A$. phagocytophilum (SHEN et al., 2018). The qPCR technique developed in the present study did not cross-reacted with $A$. phagocytophilum in either specificity test.

Other hydrolysis probe-qPCR assays have been described within the existing literature (BANETH et al., 2009; THOMPSON et al., 2018). The qPCR assay described by BANETH et al. (2009) targets the E. canis-16S rDNA sequence. Unlike other bacteria with multiple copies of $16 \mathrm{~S}$ rDNA, E. canis has only one copy of this molecular marker (MAVROMATIS et al., 2006). The gene that encodes the outer membrane $28 \mathrm{kDa}$ protein has multiple copies in the E. canis genome (MCBRIDE et al., 1999). Therefore, when $p 28$ is targeted, the chances of E. canis detection occurring are increased. Regarding the qPCR assay designed by THOMPSON et al. (2018), the technique targets the gltA gene, and it aims at Ehrlichia genus-detection displaying a lower specificity level when compared to the current study.

The qPCR targeting the p28 gene developed in this research proved to be suited to $E$. canis detection according to MIQE Guidelines (BUSTIN et al., 2009), displaying an adequate efficiency even upon a challenge $(E=98.84-100 \%)$ with no statistical difference between the values, and an excellent determination coefficient (99-99.8\%). A limitation to the $p 28$-qPCR developed in this study, which is an expected drawback to all DNA-based detection methods, regards the possibility of the appearance of mutations in the sequences targeted by the primers and probes due to the emergence of new divergent pathogen strains. The present study attempted to confront this limitation by choosing conserved regions of $p 28$ gene sequences of E. canis. However, this concern cannot be dismissed.

Considering the comparison of techniques performed in this study, the McNemar test has shown a significantly higher qPCR sensitivity over cPCR ( $p$ $<0.05)$. The samples included in the discordant pair group - meaning the samples tested positively by qPCR and negatively by cPCR — had many copies with a lower detection limit than the detection limit of cPCR. The cPCR uses agarose gels to reveal the results, which are not as precise as $\mathrm{qPCR}$ due to a low sensibility, revealing changes of about tenfold (TRIPATHI, 2010). On the other hand, qPCR is a very sensitive method because the applied fluorescence detection systems enable the capturing of minimal signs of fluorescence, detecting as little as a twofold change (TRIPATHI, 2010).

\section{CONCLUSION}

Due to CME's veterinary importance, the process for detecting E. canis must be improved. Furthermore, reliable and accurate techniques for detecting parasites are essential to creating a therapeutic plan and monitoring both the parasitemia and the infection during treatment (SILVA et al., 2016). The qPCR targeting the $p 28$ gene developed in this study proved to be suited to E. canis detection, achieving high sensitivity and specificity compared to other methods described previously in the literature. The qPCR may also be applied routinely within any laboratory without the need for post-PCR assays and can release fast and reliable feedback to veterinarians. It can also provide a quantitative measure of parasites even in samples with low copy numbers, indicating that it is useful in detecting clinical and subclinical patients. This characteristic allows clinicians to monitor the efficiency of different therapeutic protocols for ehrlichiosis.

\section{ACKNOWLEDGEMENTS}

This study was financed in part by the Coordenação de Aperfeiçoamento de Pessoal de Nível Superior - Brasil (CAPES). We also have to thank the Conselho Nacional de Desenvolvimento Científico e Tecnológico (CNPq) and the 'Carlos Chagas Filho' Fundação de Amparo à Pesquisa do Estado do Rio de Janeiro (FAPERJ) for the financial support.

\section{BIOETHICS AND BIOSECURITY COMMITTEE APPROVAL}

The research ethics committee approved these procedures of the Universidade Federal Rural do Rio de Janeiro (UFRRJ) (protocol number: 3915240616).

\section{DECLARATION OF CONFLICT OF INTEREST}

The authors declare no conflict of interest. The founding sponsors had no role in the study's design; in the collection, analyses, or interpretation of data; in the writing of the manuscript, and in the decision to publish the results.

\section{AUTHORS' CONTRIBUTIONS}

All authors contributed equally to the conception and writing of the manuscript. All authors critically revised the manuscript and approved the final version.

\section{REFERENCES}

AYAN, A. et al. High prevalence of Ehrlichia canis in dogs in Van, Turkey. Applied Ecology and Environmental Research, v.18, 
p.1953-1960. 2020. Available from: <http://dx.doi.org/10.15666/ aeer/1801 19531960>. Accessed: Feb. 03, 2020.

AGUIAR, D. M. et al. Uncommon Ehrlichia canis infection associated with morulae in neutrophils from naturally infected dogs in Brazil. Transboundary and emerging diseases, v.67, p.135-141. 2020. Available from: <https://doi.org/10.1111/ tbed.13390>. Accessed: Oct. 03, 2020.

BANETH, G. et al. Longitudinal quantification of Ehrlichia canis in an experimental infection with comparison to natural infection. Veterinary microbiology, v.136, p.321-325. 2009. Available from: $<$ https://doi. org/10.1016/j.vetmic.2008.11.022>. Accessed: Jan. 03, 2018.

BHOORA, R. et al. Development and evaluation of real-time PCR assays for the quantitative detection of Babesia caballi and Theileria equi infections in horses from South Africa. Veterinary Parasitology, v.168, p.201-211. 2010. Available from: <https:// doi.org/10.1016/j.vetpar.2009.11.011>. Accessed: Sep. 15, 2015.

BRINKHOF, B. et al. Development and evaluation of canine reference genes for accurate quantification of gene expression. Analytical Biochemistry, v.356, p.36-43. 2006. Available from: <https://doi. org/10.1016/j.ab.2006.06.001>. Accessed: Nov. 22, 2008

BUNRODDITH, K. et al. QCM-based rapid detection of PCR amplification products of Ehrlichia canis. Analytica Chimica Acta, v.1001, p.106-111. 2018. Available from: <https://doi org/10.1016/j.aca.2017.10.037>. Accessed: Jun. 29, 2019.

BUSTIN, S. et al. The MIQE guidelines: minimum information for publication of quantitative real-time PCR experiments. Clinical Chemistry, v.55, p.611-622. 2009. Available from: $<$ https://doi. org/10.1373/clinchem.2008.112797>. Accessed: Nov. 02, 2014.

DA COSTA, R. L. et al. Molecular characterization of Ehrlichia canis from naturally infected dogs from the state of Rio de Janeiro. Brazilian Journal of Microbiology, v.50. p.1-12. 2019. Available from: $<$ https://doi.org/10.1007/s42770-018-0020-7>. Accessed: Mar. 14, 2020.

DE CASTRO, M. B. et al. Experimental acute canine monocytic Ehrlichiosis: clinicopathological and immunopathological findings. Veterinary Parasitology, v.119, n.1, p.73-86, 5 jan. 2004. Available from: <https://doi.org/10.1016/j.vetpar.2003.10.012>. Accessed: Jul. 17, 2010.

DE ECHAIDE, S. T. et al. Detection of cattle naturally infected with Anaplasma marginale in a region of endemicity by nested PCR and a competitive enzyme-linked immunosorbent assay using recombinant major surface protein 5. Clinical Microbiology, v.36, p.777-782. 1998. Available from: $<$ https://doi.org/10.1128/ JCM.36.3.777-782.1998>. Accessed: Sept. 09, 2014.

DOYLE, C. et al. Detection of medically important Ehrlichia by quantitative multicolor TaqMan real-time polymerase chain reaction of the dsb gene. The Journal of molecular diagnostics: $J M D$, v.7, p.504-510. 2005. Available from: <https://doi. org/10.1016/S1525-1578(10)60581-8>. Accessed: Dec. 03, 2014.

HARRUS, S. et al. Ehrlichia canis infection. In: SYKES, J. AND GREENE C. Infectious Diseases of the Dog and Cat. Fourth ed. Michigan. Elsevier Saunders. 2012. pp. 227-238.

HSIEH, Y. C. et al. Detection and characterization of four novel genotypes of Ehrlichia canis from dogs. Veterinary Microbiology, v.146, p.70-75. 2010. Available from: <https://doi.org/10.1016/j. vetmic.2010.04.013>. Accessed: Oct. 09, 2015.

KIM, C. et al. Diagnostic real-time PCR assay for the quantitative detection of Theileria equi from equine blood samples. Veterinary Parasitology, v.151, p.158-163. 2008. Available from <https://doi. org/10.1016/j.vetpar.2007.10.023>. Accessed: Oct. 25, 2014.

KUMAR, S. et al. MEGA7: Molecular Evolutionary Genetics Analysis version 7.0 for bigger datasets. Molecular Biology Evolutionary, v.33, p.1870-1874. 2016. Available from: <https:// doi.org/10.1093/molbev/msw054>. Accessed: Jan. 10, 2017.

LINHARES, G. F. et al. Assessment of primers designed from the small ribosomal subunit RNA for specific discrimination between Babesia bigemina and Babesia bovis by PCR. Ciencia Animal Brasileira, v.3, p.27-32. 2002. Available from: <http://www. revistas.ufg.br/index.php/vet/article/view/288/256>. Accessed: Jun. 17, 2019

LYMBERY, A. J., THOMPSON, R. C. A. The molecular epidemiology of parasite infections: tools and applications. Molecular and Biochemical Parasitology, v.181, p.102116. 2012. Available from <https://doi.org/10.1016/j. molbiopara.2011.10.006>. Accessed: Jul. 31, 2015.

MAVROMATIS, $K$. et al. The genome of the obligately intracellular bacterium Ehrlichia canis reveals themes of complex membrane structure and immune evasion strategies. Journal of Bacteriology, v.188, p.4015-4023. 2006. Available from: $<$ https:// doi.org/10.1128/JB.01837-05>. Accessed: Jan. 15, 2014.

MCBRIDE, J. W. et al. Molecular cloning of the gene for a conserved major immunoreactive 28-kilodalton protein of Ehrlichia canis: a potential serodiagnostic antigen. Clinical Diagnostic Laboratory Immunity, v.6, p.392-399. 1999.

MYLONAKIS, M. E. et al. Chronic canine ehrlichiosis (Ehrlichia canis): a retrospective study of 19 natural cases. Journal of the American Animal Hospital Association, v.40, p.174-184, 2004. Available from: <https://doi.org/10.5326/0400174>. Accessed: Dec. 18,2019

NAKAGHI, A. C. H. et al. Sensitivity evaluation of a single-step PCR assay using the Ehrlichia canis p28 gene as a target and its application in the diagnosis of canine ehrlichiosis. Revista Brasileira de Parasitologia Veterinária, v.19, p.75-79. 2010. Available from: <https://doi.org/10.4322/rbpv.01902001>. Accessed: Oct. 30, 2014.

NICHOLSON, W. L. et al. The increasing recognition of rickettsial pathogens in dogs and people. Trends in Parasitology, v.26, p.205-12. 2010.Available from: <https://doi.org/10.1016/j. pt.2010.01.007>. Accessed: Dec. 07, 2015.

OTRANTO, D. et al. Diagnosis of Hepatozoon canis in young dogs by cytology and PCR. Parasites \& Vectors, v.55, p.1-6. 2011. Available from: <https://doi.org/10.1186/1756-3305-4-55>. Accessed: Jun. 08, 2018

PAULINO, P. G. et al. Comparison of heat shock protein $70 \mathrm{kDa}$ and $18 S$ rDNA genes for molecular detection and phylogenetic analysis of Babesia vogeli from whole blood of naturally infected dogs. Ticks and Tick-Borne Diseases, v.9, p.556-562. 2018. Available from: <https://doi.org/10.1016/j.ttbdis.2018.01.013>. Accessed: Dec. 18, 2019.

Ciência Rural, v.51, n.12, 2021. 
PELEG, O. et al. Multiplex real-time qPCR for the detection of Ehrlichia canis and Babesia canis vogeli. Veterinary Parasitology, v.29, p.3-4. 2010. Available from: <https://doi. org/10.1016/j.vetpar.2010.06.039>. Accessed: Jul. 18, 2019.

PUSTERLA, N. et al. Detection and quantitation of Ehrlichia risticii genomic DNA in infected horses and snails by real-time PCR. Veterinary Parasitology, v.90, p.129-135. 2009. Available from: $\quad<$ https://doi.org/10.1016/S0304-4017(00)00227-2>. Accessed: Jul. 21, 2011.

QUROLLO, B. A. et al. Improved molecular detection of Babesia infections in animals using a novel quantitative real-time PCR diagnostic assay targeting mitochondrial DNA. Parasites \& Vectors, v.10, 2017. Available from: <https://doi.org/10.1186/ s13071-017-2064-1>. Accessed: Oct. 16, 2019.

QUROLLO, B. A. et al. Development and validation of a sensitive and specific $\operatorname{sodB}$-based quantitative PCR assay for molecular detection of Ehrlichia species. Journal of Clinical Microbiology, v.52, p.4030-4032. 2014. Available from: <https://doi.org/10.1128/ JCM.02340-14>. Accessed: Dec. 18, 2017.

RODRÍGUEZ-ALARCÓN, C. A. et al. Demonstrating the presence of Ehrlichia canis DNA from different tissues of dogs with suspected subclinical ehrlichiosis. Parasites and Vectors, v.13, p.518. 2020. Available from: <https://doi.org/10.1186/ s13071-020-04363-0>. Accessed: Dec. 13, 2020.

SALES, M. R. R. P. et al. Prevalence of Ehrlichia canis using the nested-PCR, correlation with the presence of morulae and thrombocytopenia in $\operatorname{dog} s$ treated in Veterinary Hospital of the Federal University of Espirito Santo. Revista Brasileira de Medicina Veterinária, v.37, p.47-51, 2015. Available from $<$ http://rbmv.org/index.php/BJVM/article/view/360>. Accessed: Dec. 18, 2019

SANTOS, H. A. et al. Molecular epidemiology of the emerging zoonosis agent Anaplasma phagocytophilum (Foggie, 1949) in dogs and ixodid ticks in Brazil. Parasites \& Vectors, v.348, p.110. 2013. Available from: <https://doi.org/10.1186/1756-3305-6348>. Accessed: Nov. 08, 2019.

SHEN, Z. et al. Development of a tick-borne pathogen QPCR panel for detection of Anaplasma, Ehrlichia, Rickettsia, and Lyme disease Borrelia in animals. Journal of Microbiology Methods, v.151., p.83-89. 2018. Available from: <https://doi.org/10.1016/j. mimet.2018.05.019>. Accessed: Dec. 18, 2019.

SILVA, C. B. et al. A new quantitative PCR method for the detection of Anaplasma platys in dogs based on the citrate synthase gene. Journal of Veterinary Diagnostic Investigation, v.28, p.529-535. 2016. Available from: <https://doi. org/10.1177/1040638716659101>. Accessed: Nov. 01, 2018.

SVEC, D. et al. How good is a PCR efficiency estimate: recommendations for precise and robust $\mathrm{qPCR}$ efficiency assessments? Biomolecular Detection and Quantification, v.3, p.9-16. 2015. Available from: <http://dx.doi.org/10.1016/j. bdq.2015.01.005>. Accessed: Dec. 16, 2017.

SOARES, J. F. et al. Detection and molecular characterization of a canine piroplasm from Brazil. Veterinary Parasitology, v.180, p.203-208. 2011. Available from: <http://dx.doi.org/10.1016/j. vetpar.2011.03.024>. Accessed: Dec. 08, 2014.

TRIPATHI, G. Polymerase chain reaction: in vitro amplification of DNA. In: JAISWAL, MK Cellular and biochemical science. New Delhi: International Pvt Ltd, 2010. p.683-684.

THOMPSON, K. et al. A new TaqMan method for the reliable diagnosis of Ehrlichia spp. in whole canine blood. Parasites \& Vectors, v.11, p. 350. 2018. Available from: <https://doi. org/10.1186/s13071-018-2914-5>. Accessed: Mar. 18, 2019.

VELOSO, J. F. et al. Molecular diagnosis of Ehrlichia canis infection in dogs with uveitis Semina: Ciências Agrárias, Londrina, v.39, p.1049-1056, 2018. Available from: <http:// dx.doi.org/10.5433/1679-0359.2018v39n3p1049>. Accessed: Dec. $18,2019$.

VIEIRA, R. F., et al. Ehrlichiosis in Brazil Revista Brasileira de Parasitologia Veterinária, v.20, p.1-12. 2011. Available from: <http://dx.doi.org/10.1590/S1984-29612011000100002>. Accessed: Nov. 12, 2014.

WANER T. et al. Characterization of the subclinical phase of canine ehrlichiosis in experimentally infected beagle dogs. Veterinary Parasitology, v.69. p.307-317. 1997. Available from: $<$ https://doi. org/10.1016/S0304-4017(96)01130-2>. Accessed: Mar. 20, 2015. 